\title{
ВПЛИВ ГОСТРОЇ КРОВОВТРАТИ, УСКЛАДНЕНОЇ ІШЕМІЄЮ-РЕПЕРФУЗІЄЮ КІНЦІВКИ, НА АКТИВНІСТЬ ПРОЦЕСІВ ЛІПІДНОЇ ПЕРОКСИДАЦІЇ У ЛЕГЕНЯХ ТА ЇХ КОРЕКЦІЯ КАРБАЦЕТАМОМ
}

\begin{abstract}
Вплив гострої крововтрати, ускладненої ішемієюреперфузією кінцівки, на активність процесів ліпідної пероксидації у легенях та їх корекція карбацетамом
\end{abstract}

\section{О. В. Стахів, Р. В. Максимів}

ТОВ «Клініка ендоскопічної та пластичної хірургії Стахіва» Тернопільський національний медичний університет імені І. Я. Горбачевського МОЗ України

Резюме. Останнім часом відмічають значне зростання частоти терористичних атак і локальних збройних конфрліктів. Їх характерною ознакою стало збільшення числа поранених 3 масивною зовнішньою кровотечею, які вимагають негайного застосування кровоспинного джгута з максимальним безпечним терміном повної ішемії кінцівки до 2 год. Доведено, що ішемія кінцівки та гостра крововтрата сприяють ініціації процесів ліпідної пероксидації завдяки посиленій продукції активних фрорм кисню.

Мета дослідження - з'ясувати вплив гострої крововтрати, ускладненої ішемією-реперфузією кінцівки, на інтенсивність процесів ліпідної пероксидації легень та ефрективність корекції виявлених порушень карбацетамом.

Матеріали і методи. Дослідження проведено на 216 білих нелінійних щурах-самцях масою 200-220 г. Усі експерименти виконані під тіопентал-натрієвим наркозом. У тварин моделювали ішемію-реперфрузію кінцівки, гостру крововтрату та поєднували ці ушкодження. В окремій групі проводили корекцію виявлених порушень карбацетамом. Через 1 і 2 год, а також через 1; 7 i 14 діб у дослідних тварин визначали вмісти реагентів до тіобарбітурової кислоти, що належить до скринінгових показників активності процесів ліпідної пероксидації.

Результати. За умов ішемії-реперфузії кінцівки, гострої крововтрати та їх поєднання у легенях зростає вміст реагентів до тіобарбітурової кислоти. Якщо після моделювання лише ішемії-реперфруії кінцівки показник до 14 доби нормалізується, то після моделювання гострої крововтрати та її ускладнення ішемієюреперфузією кінцівки показник хвилеподібно зростає 3 першим максимумом через 1 добу і другим через 14 діб й суттєво перевищує контрольний рівень. Ускладнення гострої крововтрати ішемією-реперфузією кінцівки у всі терміни супроводжується більшим вмістом реагентів до тіобарбітурової кислоти, порівняно з інши-
Influence of acute blood loss complicated by limb ischemia-reperfusion on the activity of lipid peroxidation processes in lungs and their correction with carbacetam

\section{O. V. Stakhiv, R. V. Maksymyv}

Stakhiv Endoscopic and Plastic Surgery Clinic

I. Horbachevsky Ternopil National Medical University

e-mail: arsgudyma@gmail.com

Summary. Recently, there has been a significant increase in the frequency of terrorist attacks and local armed conflicts. Their characteristic feature was an increase in the number of wounded with massive external bleeding, which require immediate use of a tourniquet with the maximum safe period of complete ischemia of the limb up to 2 hours. It is proved that ischemia of the limb and acute blood loss contribute to the initiation of lipid peroxidation due to increased production of reactive oxygen species.

The aim of the study - to determine the effect of acute blood loss complicated by limb ischemia-reperfusion on the intensity of lipid peroxidation of the lungs and the effectiveness of correction of detected disorders by carbacetam.

Materials and Methods. The study was performed on 216 white nonlinear male rats weighing 200-220 g. All experiments were performed under thiopental-sodium anesthesia. In animals, limb ischemia-reperfusion and acute blood loss were simulated and these lesions were combined. In a separate group, the detected disorders were corrected with carbacetam. After 1 and 2 hours, as well as after 1, 7 and 14 days in experimental animals, the content of reagents to thiobarbituric acid was determined, which belongs to the screening indicators of the activity of lipid peroxidation processes.

Results. Under conditions of ischemia-reperfusion of the limb, acute blood loss and their combination in the lungs increases the content of reagents to thiobarbituric acid. If after modeling only ischemia-reperfusion of the limb the figure is normalized up to 14 days, then after modeling acute blood loss and its complication by ischemia-reperfusion of the limb, the figure increases with the first maximum after 1 day and the second after 14 days and significantly exceeds the control level. Complications of acute blood loss by ischemia-reperfusion of the limb at all times is accompanied by a higher content of reagents to thiobarbituric acid 
ми дослідними групами, що дозволяє припустити ефрект взаємного обтяження з виснаженням фракторів антиоксидантного захисту. Під впливом карбацетаму в усіх дослідних групах показник статистично вірогідно знижується, що вказує на виражений антиоксидантний ефрект препарату. Хоча показники не досягали рівня контрольної групи, карбацетам можна вважати перспективним засобом корекції прооксидантних порушень у легенях за умов гострої крововтрати, ускладненої ішемією-реперфузією кінцівки.

Висновки. За умов ішемії-реперфузії кінцівки, гострої крововтрати та їх поєднання у легенях посилюються прочеси ліпідної перосидації, що виявляють зростанням вмісту реагентів до тіобарбітурової кислоти. Унаслідок моделювання гострої крововтрати, ускладненої ішемією-реперфузією кінцівки, порушення $\epsilon$ більшими у всі терміни спостереження. Застосування карбацетаму через 7-14 діб знижує вміст реагентів до тіобарбітурової кислоти у всіх дослідних групах, що вказує на перспективність засобу для корекції виявлених порушень.

Ключові слова: гостра крововтрата; ішемія-реперфузія кінцівки; реагенти до тіобарбітурової кислоти; легені; карбацетам.

\section{ВСТУП}

Останнім часом відмічають значне зростання частоти терористичних атак і локальних збройних конфлліктів. Їх характерною ознакою стало збільшення числа поранених із масивною зовнішньою кровотечею, які вимагають негайного застосування кровоспинного джгута з максимальним безпечним терміном повної ішемії кінцівки до 2 год [1].

Як показує практика, навіть ефективне застосування джгута в екстремальних умовах при пораненнях кінцівок часто поєднується з масивною крововтратою. Доведено, що ішемія кінцівки та гостра крововтрата [2] сприяють ініціації процесів ліпідної пероксидації завдяки посиленій продукції активних фрорм кисню [3].

Однак системний вплив гострої крововтрати та ішемії-реперсузії кінцівки на стан ліпідної пероксидації в легенях - одному з найчутливіших органів до непрямих ушкоджувальних впливів, вивчений недостатньо. Немає даних щодо ефективності за цих умов карбацетаму, який здатний нівелювати інтенсивність ліпопероксидації за умов гострої крововтрати, ускладненої ішемією-реперфузією кінцівки у нирках та печінці [4].

Метою дослідження було з'ясувати вплив гострої крововтрати, ускладненої ішемією-реперфрузією кінцівки, на інтенсивність процесів ліпідної пероксидації легень та ефективність корекції виявлених порушень карбацетамом.

\section{МАТЕРІАЛИ I МЕТОДИ}

Дослідження проведено на 216 білих нелінійних щурах-самцях віком 6-8 місяців масою 200- compared to other experimental groups, which suggests a mutual burden with the depletion of antioxidant protection factors. Under the influence of carbacetam in all experimental groups the indicator is statistically significantly reduced, which indicates a pronounced antioxidant effect of the drug. Although the indicators did not reach the level of the control group, carbacetam can be considered a promising means of correction of prooxidant disorders in the lungs in conditions of acute blood loss complicated by ischemia-reperfusion of the limb.

Conclusions. Under conditions of ischemia-reperfusion of the limb, acute blood loss and their combination in the lungs, the processes of lipid peroxidation are intensified, which is manifested by an increase in the content of reagents to thiobarbituric acid. Due to the simulation of acute blood loss complicated by ischemia-reperfusion of the limb, the violations are greater in all terms of observation. The use of carbacetam after 7-14 days reduces the content of reagents to thiobarbituric acid in all experimental groups, which indicates the prospects of the tool for the correction of detected disorders

Key words: acute blood loss; ischemia-reperfusion of the limb; reagents for thiobarbituric acid; lungs; carbocetam.

220 г, яких утримували в одному приміщенні при постійній температурі $18-22{ }^{\circ} \mathrm{C}$ на стандартному режимі віварію. Усі експерименти виконано 3 дотриманням норм Конвенції Ради Європи про захист хребетних тварин, що використовуються для досліджень та інших наукових цілей (Страсбург, 1986), ухвали Першого національного конгресу 3 біоетики (Київ, 2001) і наказу МОЗ України № 690 від 23.09.2009 р. Комісія з питань біоетики Тернопільського національного медичного університету імені І. Я. Горбачевського МОЗ України порушень морально-етичних норм при проведенні науководослідної роботи не виявила.

Усі експерименти виконані під тіопентал-натрієвим наркозом (40 мг/кг). Усіх тварин поділили на п'ять груп: контрольну (6 щурів) та чотири дослідних. У першій дослідній групі (50 щурів) тваринам моделювали ішемію-реперфузію кінцівки шляхом накладання проксимально на ліву лапку смужку еластичного джгута «SWAT-T» (США) шириною 10 мм на 120 хв [4]. В другій дослідній групі (50 щурів) моделювали гостру крововтрату (20\% від об'єму циркулюючої крові) шляхом пересікання стегнової вени. У третій дослідній групі ці ушкодження поєднували (50 щурів). У четвертій дослідній групі тваринам 3 ішемією-реперфузією кінцівки (20 щурів), з гострою крововтратою (20 щурів) та їх поєднанням (20 щурів) внутрішньочеревно вводили карбацетам (Інститут фрізикоорганічної хімії та вуглехімії НАН України, Донецьк) в дозі 5 мг на кілограм маси тварини [4].
ISSN 2706-6282(print)

ISSN 2706-6290(online)
Вісник медичних і біологічних досліджень

Bulletin of Medical and Biological Research
$3(5), 2020$ 
В контрольній групі тварин тільки вводили в наркоз і в подальшому брали для досліджень через 3 год.

Через 1 і 2 год, а також через 1; 7 і 14 діб дослідних тварин першої, другої і третьої груп, а також через 7 і 14 діб дослідних тварин четвертої групи виводили з експерименту методом тотального кровопускання з серця. Для досліджень брали легені, в гомогенаті яких за методикою [5] визначали вміст реагентів до тіобарбітурової кислоти (ТБК-АП), які належать до скринінгових показників активації продуктів ліпідної пероксидації.

Оцінку вірогідності відмінностей між експериментальними групами проводили з використанням непараметричного критерію Манна - Уїтні.

\section{РЕЗУЛЬТАТИ Й ОБГОВОРЕННЯ}

Дослідження показали, що вміст ТБК-АП у легенях, порівняно 3 контрольною групою, статично вірогідно зростав у всіх дослідних групах (табл. 1, рис.). Так, у тварин, яким моделювали ішеміюреперфузію, показник зріс через 1 год в 2,1 раза, через 2 год - в 2,5 раза, через 1 добу - в 2,0 рази і через 7 діб - на 62,3 \% (р<0,05). Варто відмітити, що через 14 діб реперфузійного періоду вміст ТБКАП у гомогенаті легень практично не відрізнявся від даних контрольної групи $(p<0,05)$. В динаміці показник досягав максимуму через 2 год після експериментальної ішемії-реперфузії. У цей термін показник був вищий на 17,3 \% (p<0,05) порівняно з результатом 1 год. Через 1 добу експерименту показник вірогідно не відрізнявся від даних через 1 год ( $>>0,05)$, але на 19,5 \% ( $<<0,05)$ був нижчим відносно даних через 2 год спостереження. Через 7 діб експерименту вміст ТБК-АП на 19,2 \% був нижчим від показника через 1 добу $(p<0,05)$, на
34,9 \% - стосовно 2 год експерименту $(p<0,05)$, на 23,6 \% - стосовно 1 год експерименту. Через 14 діб вміст ТБК-АП у легенях вірогідно був нижчим стосовно даних 7; 1 доби та 2 і 1 год спостереження (відповідно на 39,7; 51,3; 60,7; 53,9 \%, р<0,05).

У щурів, яким моделювали гостру крововтрату, вміст ТБК-АП у гомогенаті легень стосовно контрольної групи вірогідно підвищився вже через 1 год - в 2,2 раза $p<0,05)$. Через 2 год показник, порівняно з контрольною групою, зростав у 2,8 раза, через 1 добу - в 5,2 раза, через 7 діб - у 3,5 раза, через 14 діб - в 4,8 раза ( $p<0,05)$. У динаміці максимальний вміст ТБК-АП в легенях відмічали через 1 добу після експериментальної крововтрати. Через 2 год показник був вищий на 25,8 \% ( $<<0,05)$ стосовно даних через 1 год. Через 1 добу експерименту показник вірогідно перевищував дані через 1 год спостереження - в 2,3 раза, та дані через 2 год спостереження - в 1,9 раза $(p<0,05)$. Через 7 діб експерименту вміст ТБК-АП був нижчим на 32,5 $\%$, порівняно з показником через 1 добу $(p<0,05)$, на 25,6 \% перевищував результат 2 год експерименту $(p<0,05)$ та на 58,1 \% відносно 1 год спостереження $(p<0,05)$. Через 14 діб експерименту вміст ТБК-АП істотно не відрізнявся від показника через 1 добу спостереження та вірогідно перевищував дані 1 і 2 год та 7 діб експерименту - у 2,1; 1,7 раза та на 35,1 \% відповідно ( $p<0,05)$.

У щурів, яким моделювали крововтрату, ускладнену ішемією-реперфузією кінцівки, вміст ТБК-АП у гомогенаті легень стосовно контрольної групи вірогідно підвищився через 1 год в 3,2 раза, через 2 год - у 4,0 рази, через 1 добу - в 6,3 раза, через 7 діб - у 5,3 раза, через 14 діб - в 6,0 разів відповідно ( $p<0,05)$. У динаміці показник теж досягав максимуму через 1

Таблиця 1. Зміни вмісту ТБК-АП (нмоль/г тканини) в гомогенаті легень щурів після гострої крововтрати, ускладненої ішемією-реперфузією кінцівки (Ме (Q25; Q75))

\begin{tabular}{|c|c|c|c|c|c|}
\hline \multirow{3}{*}{ Дослідна група } & \multicolumn{5}{|c|}{ Термін реперсузійного періоду } \\
\hline & 1 год & 2 год & 1 доба & 7 доба & 14 доба \\
\hline & \multicolumn{5}{|c|}{ Контроль = 2,39 $(2,08 ; 2,61)(n=6)$} \\
\hline $\begin{array}{l}\text { Перша } \\
\text { Ішемія-реперфрузія }\end{array}$ & $\begin{array}{c}5,08^{\star} \\
(4,84 ; 5,59) \\
(n=10)\end{array}$ & $\begin{array}{c}5,96^{* 1 r} \\
(5,49 ; 6,62) \\
(n=10)\end{array}$ & $\begin{array}{c}4,80^{* 25} \\
(4,46 ; 5,73) \\
(n=10)\end{array}$ & $\begin{array}{c}3,88^{* 1,2,2 r, 1 A} \\
(3,64 ; 4,23) \\
(n=10)\end{array}$ & $\begin{array}{c}2,34^{1 г, 2 \Gamma, 1 д, 7 \AA} \\
(2,18 ; 2,53) \\
(n=10)\end{array}$ \\
\hline$\overline{p_{1-2}}$ & $p>0,05$ & $p<0,05$ & $p<0,05$ & $p<0,05$ & $p<0,05$ \\
\hline $\begin{array}{l}\text { Друга } \\
\text { Крововтрата }\end{array}$ & $\begin{array}{c}5,34^{\star} \\
(5,13 ; 5,53) \\
(n=10)\end{array}$ & $\begin{array}{c}6,72^{* 1 r} \\
(6,02 ; 7,06) \\
(n=10)\end{array}$ & $\begin{array}{c}12,50^{* 11,2 r} \\
(11,9 ; 13,0) \\
(n=9)\end{array}$ & $\begin{array}{c}8,44^{* 1,2,2 r, 1 A} \\
(7,76 ; 8,68) \\
(n=8)\end{array}$ & $\begin{array}{c}11,40^{* 11,22,7 \AA} \\
(10,6 ; 12,3) \\
(n=8)\end{array}$ \\
\hline$p_{2-3}$ & $p<0,05$ & $p<0,05$ & $p>0,05$ & $p<0,05$ & $p<0,05$ \\
\hline $\begin{array}{l}\text { Третя } \\
\text { Ішемія-реперфуузія+ } \\
\text { крововтрата }\end{array}$ & $\begin{array}{c}7,54^{\star} \\
(6,86 ; 8,01) \\
(n=10)\end{array}$ & $\begin{array}{c}9,60 * 1 г \\
(9,06 ; 10,6) \\
(n=10)\end{array}$ & $\begin{array}{c}15,07^{* 1,2,2 r} \\
(13,4 ; 15,5) \\
(n=8)\end{array}$ & $\begin{array}{c}12,55^{* 1,2 r, 1 \mathrm{~A}} \\
(11,6 ; 13,9) \\
(\mathrm{n}=8)\end{array}$ & $\begin{array}{c}14,40 * 1,2 г \\
(14,0 ; 16,6) \\
(n=8)\end{array}$ \\
\hline$p_{1-3}$ & $p<0,05$ & $p<0,05$ & $p<0,05$ & $p<0,05$ & $p<0,05$ \\
\hline
\end{tabular}

Примітки: 1) * - відмінності стосовно контрольної групи статистично вірогідні $(\mathrm{p}<0,05)$;

2) $\mathrm{p}_{1-2}$ - вірогідність відмінностей між першою і другою дослідними групами;

3) $p_{2-3}$ - вірогідність відмінностей між другою і третьою дослідними групами;

4) $\mathrm{p}_{1-3}$ - вірогідність відмінностей між першою і третьою дослідними групами. 


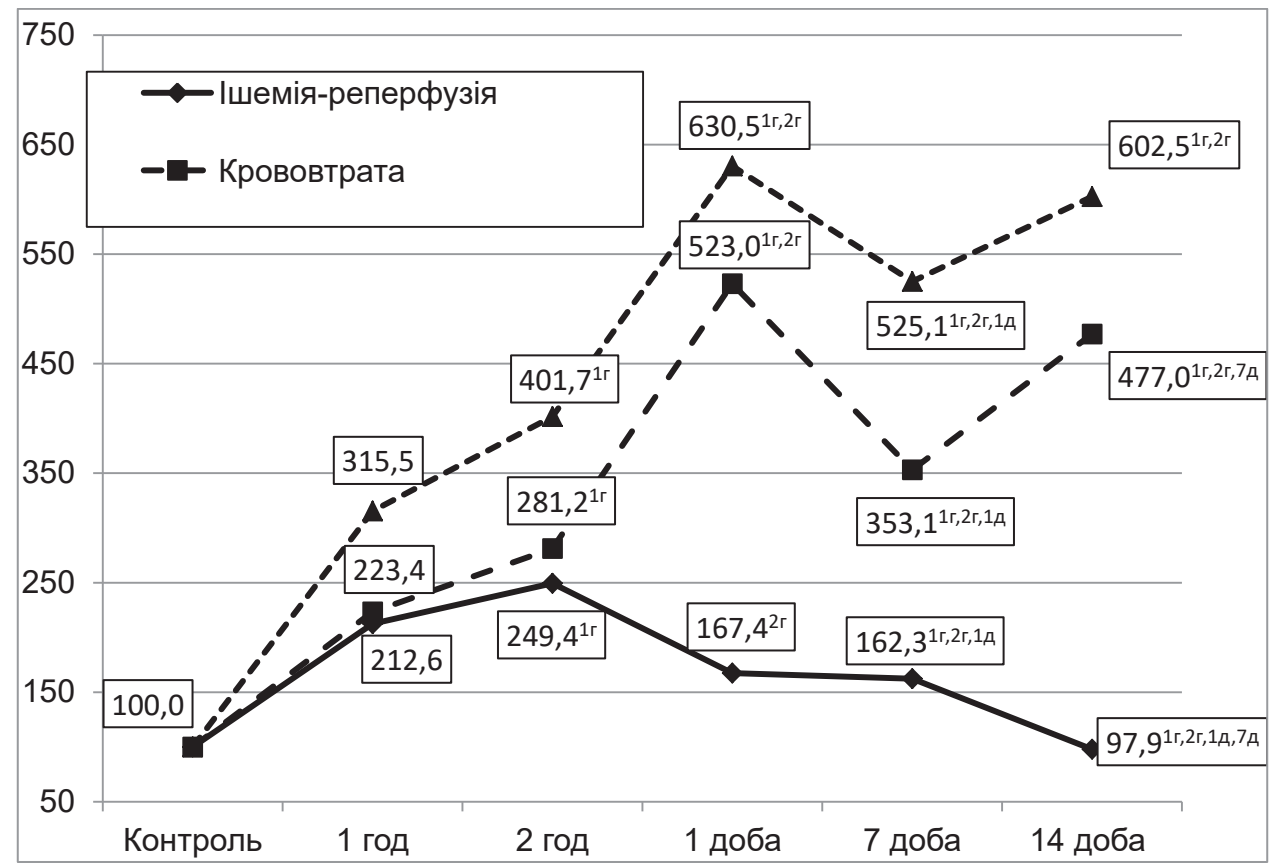

Рис. Динаміка вмісту ТБК-АП в гомогенаті легень щурів (у відсотках до рівня контрольної групи) після гострої крововтрати, ускладненої ішемією-реперфузією кінцівки.

Примітка. 1,2г,1д,7д - відмінності стосовно 1 і 2 год, а також 1 і 7 діб експерименту статистично вірогідні, p<0,05.

добу спостереження. Через 2 год даний показник був вищий на 27,3\% стосовно даних через 1 год $(p<0,05)$. Через 1 добу експерименту показник вірогідно перевищував дані через 1 год спостереження - в 2,0 рази $(p<0,05)$, та дані через 2 год спостереження - на $57,0 \%(p<0,05)$. Через 7 діб експерименту вміст ТБКАП вірогідно був нижчим на 16,7 \% від показника через 1 добу ( $<<0,05)$, на 30,7 \% перевищував дані 2 год експерименту $(p<0,05)$ та на 66,4 \% дані 1 год спостереження $(p<0,05)$. Через 14 діб експерименту вміст ТБК-АП вірогідно не відрізнявся від показника через 1 та 7 доби спостереження ( $>>0,05)$ та вірогідно перевищував дані через 1 та 2 год експерименту (відповідно на 91,0; 50,0\%, p<0,05).

Дослідження показників пероксидного окиснення ліпідів у тканині легень тварин за умов корекції карбацетамом показало (табл. 2), що після моделювання лише ішемії-реперфузії кінцівки, порівняно $з$ тваринами без корекції, вміст ТБК-АП через 7 діб експерименту ставав на 27,6 \% меншим $(p<0,05)$. Через 14 діб вміст ТБК-АП вірогідно не відрізнявся від контрольної групи як за умови корекції, так і без неї (p>0,05).

У щурів, яким моделювали крововтрату, вміст ТБК-АП у тканині легень під впливом карбацетаму, порівняно з тваринами без корекції, через 7 діб експерименту ставав на 27,6 \% меншим ( $<00,05)$, через 14 діб - від показника без корекції, а на 14 добу спостереження - на 23,8 \% $(p<0,05)$.

У щурів після гострої крововтрати, ускладненої ішемією-реперфузією кінцівки, застосування кар- бацетаму зумовлювало суттєве зниження вмісту ТБК-АП у легенях через 7 діб - на 16,0 \%, а на 14 добу спостереження - на 22,2 \% порівняно 3 тваринами без корекції $(p<0,05)$.

Таким чином, наші дослідження показали, що за умов двогодинної ішемії кінцівки, гострої крововтрати та їх поєднання в легенях дослідних тварин активуються процеси ліпідної пероксидації, що виявляли на основі збільшення вмісту ТБК-АП. Якщо після моделювання лише ішемії-реперфузії кінцівки показник до 14 доби нормалізувався, то після моделювання гострої крововтрати та ії ускладнення ішемією-реперфузією кінцівки вміст у легенях ТБК-АП хвилеподібно зростав з першим максимумом через 1 добу і другим через 14 діб й суттєво перевищував контрольний рівень. Ускладнення гострої крововтрати ішемією-реперфузією кінцівки у всі терміни супроводжувалося більшим вмістом ТБК-АП, порівняно з іншими дослідними групами, що дозволяє припустити ефект взаємного обтяження з виснаженням фракторів антиоксидантного захисту.

Отримані результати підтвердили дані інших авторів, які теж відмічали посилення процесів ліпідної пероксидації у внутрішніх органах тварин після гострої крововтрати, ускладненої ішемієюреперфузією кінцівки $[6,7]$.

В основі патогенезу виявлених порушень, як свідчать дані ряду авторів, лежить здатність двогодинного повного знекровлення кінцівки зумовлювати ушкодження нервів і судин під джгутом, 
Таблиця 2. Зміни вмісту ТБК-АП (нмоль/г тканини) у гомогенаті легень щурів після гострої крововтрати, ускладненої ішемією-реперфузією кінцівки, за умови корекції карбацетамом (Me (Q25; Q75))

\begin{tabular}{|c|c|c|c|c|}
\hline \multirow{3}{*}{ Дослідна група } & \multicolumn{4}{|c|}{ Термін реперфузійного періоду } \\
\hline & \multicolumn{2}{|c|}{ без корекції } & \multicolumn{2}{|c|}{ корекція карбацетамом } \\
\hline & 7 доба & 14 доба & 7 доба & 14 доба \\
\hline \multicolumn{5}{|c|}{ Контроль = 2,39 $(2,08 ; 2,61)(n=6)$} \\
\hline $\begin{array}{l}\text { Перша } \\
\text { Ішемія-реперфузія }\end{array}$ & $\begin{array}{c}3,88^{*} \\
(3,64 ; 4,23) \\
(n=10)\end{array}$ & $\begin{array}{c}2,34 \\
(2,18 ; 2,53) \\
(n=10)\end{array}$ & $\begin{array}{c}2,81^{\#} \\
(2,57 ; 3,23) \\
(n=10)\end{array}$ & $\begin{array}{c}2,08 \\
(1,91 ; 2,25) \\
(n=10)\end{array}$ \\
\hline$p_{1-2}$ & $<0,05$ & $<0,05$ & $<0,05$ & $<0,05$ \\
\hline $\begin{array}{l}\text { Друга } \\
\text { Крововтрата }\end{array}$ & $\begin{array}{c}8,44^{*} \\
(7,68 ; 8,57) \\
(n=8)\end{array}$ & $\begin{array}{c}11,40^{*} \\
(10,63 ; 12,26) \\
(n=8) \\
\end{array}$ & $\begin{array}{c}6,11^{* \#} \\
(5,61 ; 6,58) \\
(n=10)\end{array}$ & $\begin{array}{c}8,69^{* \#} \\
(7,87 ; 9,08) \\
(n=10)\end{array}$ \\
\hline$p_{2-3}$ & $<0,05$ & $<0,05$ & $<0,05$ & $<0,05$ \\
\hline $\begin{array}{l}\text { Tретя } \\
\text { Ішемія-реперфузія+ } \\
\text { крововтрата }\end{array}$ & $\begin{array}{c}12,55^{\star} \\
(11,59 ; 13,90) \\
(n=8)\end{array}$ & $\begin{array}{c}14,40^{\star} \\
(14,05 ; 16,55) \\
(n=8)\end{array}$ & $\begin{array}{c}10,54^{* \#} \\
(9,72 ; 11,32) \\
(n=9)\end{array}$ & $\begin{array}{c}11,20^{* \#} \\
(10,50 ; 12,10) \\
(n=9)\end{array}$ \\
\hline$p_{1-3}$ & $<0,05$ & $<0,05$ & $<0,05$ & $<0,05$ \\
\hline
\end{tabular}

Примітки: 1) * - відмінності стосовно контрольної групи статистично вірогідні $(p<0,05)$;

2) p $_{1-2}$ - вірогідність відмінностей між першою і другою дослідними групами;

3) $p_{2-3}$ - вірогідність відмінностей між другою і третьою дослідними групами;

4) $p_{13}$ - вірогідність відмінностей між першою і третьою дослідними групами;

5) ${ }^{\#-}$ вірогідність відмінностей в межах однієї групи за умови корекції карбацетамом.

міонекроз, рабдоміоліз та тромбоз глибоких вен [8, 9]. Ще більші метаболічні порушення в кінцівці виникають після її реперфузії й на системному рівні можуть зумовити метаболічний ацидоз, гіперкаліємію та міоглобінемію [10], зростання вмісту у внутрішніх органах та плазмі крові супероксид-радикалу [11], зниження загального антиоксидантного захисту [12].

Необхідно зауважити, що ініціація процесів ліпідної пероксидації створює передумови для подальшого розвитку поліорганної недостатності [13-15], оскільки часто супроводжується викидом прозапальних цитокінів. Цей фракт пітверджений за умов застосування кровоспинного джгута [16] і наводить на думку про те, що ускладнення гострої крвовотрати ішемією-реперфузією кінцівки створює більші передумови для розвитку поліорганної недостатності, що варто пам'ятати в клініці при лікуванні пацієнтів із гострою крововтратою та тривалим, навіть в межах безпечного двогодинного терміну, знекровленням кінцівки джгутом.

Враховуючи сказане, з метою корекції ми вирішили застосувати кабацетам, який добре зарекомендував себе як чинник попередження дисфункції печінки й нирок за умов гострої крововтрати, ускладненої ішемією-реперфрузією кінцівки $[4,17]$. Як показали дослідження, під впливом карбацетаму вміст ТБК-АП в легенях у всіх дослідних групах статистично вірогідно знижувався, що вказує на виражений антиоксидантний ефект препарату. Хоча показники не досягали рівня контрольної групи, карбацетам можна вважати перспективним засобом корекції прооксидантних порушень у легенях за умов гострої крововтрати, ускладненої ішемієюреперсузією кінцівки, що вимагає подальшого доклінічного вивчення.

У подальшому доцільно поглибити дослідження щодо порушень легень за умов гострої крововтрати та ішемії-реперфузії кінцівки та встановити за цих умов ключові механізми дії карбацетаму.

\section{ВИСНОВКИ}

1. За умов двогодинної ішемії кінцівки, гострої крововтрати та їх поєднання в легенях дослідних тварин активуються процеси ліпідної пероксидації, що виявляється збільшенням вмісту ТБК-АП. Після моделювання лише ішемії-реперфузії кінцівки показник до 14 доби нормалізується. Після моделювання гострої крововтрати вміст у легенях ТБК-АП хвилеподібно зростає з першим максимумом через 1 добу і другим через 14 діб й суттєво перевищує контрольний рівень. Ускладнення гострої крововтрати ішемією-реперфузією кінцівки у всі терміни супроводжувалося більшим вмістом ТБК-АП порівняно з іншими дослідними групами.

2. Застосування впродовж 7-14 діб реперфузійного періоду карбацетаму в тварин з ішемієюреперфузією кінцівки, гострою крововтратою та їх поєднанням, порівняно 3 тваринами без корекції, викликає істотне зниження вмісту в легенях ТБКАП, що свідчить про виражений антиоксидантний вплив препарату за умов модельованої патології. 


\section{СПИСОК ЛІТЕРАТУРИ}

1. An evidence-based prehospital guideline for external hemorrhage control: American College of Surgeons Committee on Trauma / E. M. Bulger, D. Snyder, K. Schoelles [et al.] // Prehosp. Emerg. Care. - 2014. No. 18. - P. 163-173.

2. Volotovska N. V. Changes in the glutathione system's activity of internal organs in the first hours of experimental limb ischemia-reperfusion syndrome, combined with blood loss and mechanical injury / N. V. Volotovska, T. Nhokwara Cliff, I. V. Zhulkevych // Здобутки клінічної і експериментальної медицини. - 2019. - № 1. - Р. 17-23.

3. Leukocytes and the inflammatory response in ischemiareperfusion injury / I. Francischetti, J. B. Moreno, M. Scholz, W. B. Yoshida // Rev. Bras. Cir. Cardiovasc. 2010. - Vol. 25 (4). - P. 575-584.

4. Шацький В. В. Динаміка антиоксидантно-прооксидантного балансу кіркового і мозкового шарів нирки після гострої крововтрати, ускладненої ішемією-реперфузією кінцівки, та його корекція карбацетамом / В. В. Шацький, А. А. Гудима, Л. Я. Федонюк // Здобутки клінічної і експериментальної медицини. - 2019. - № 4. - C. $144-153$.

5. Арутюнян А. В. Методы оценки свободнорадикального окисления и антиоксидантной системы организма : метод. рекоменд. / А. В. Арутюнян, Е. Е. Дубинина, Н. Н. Зыбина. - СПб., 2000. - 104 с.

6. Прооксидантний вплив артеріального джгута і реперфузії кінцівки : матеріали XVII конґресу Світової Федерації Українських Лікарських Товариств, 20-22 верес. 2018 р. / Р. В. Максимів, І. І. Горбань, І. В. Стрельбицька [та ін.]. - Тернопіль : ТДМУ, 2018. - С. 205.

7. Shatskyi V. V. Significance of lipid peroxidation processes in renal excretory dysfunction in cases of acute blood loss complicated by limb ischemia-reperfusion and its correction / V. V. Shatskyi, A. A. Hudyma // Journal of Education, Health and Sport. - 2019. - Vol. 9, No. 11. - P. 293-306.

8. Телев'як А. Т. Динаміка показників перекисного окиснення ліпідів та антиоксидантного захисту в м'язовій тканині задніх кінцівок щурів при розвитку ішемічно-реперфузійного синдрому / А. Т. Телев'як // Здобутки клінічної і експериментальної медицини. - 2018. - № 3(35). - C. 132-139.

\section{REFERENCES}

1. Bulger EM, Snyder D, Schoelles K, Gotschall C, Dawson D, Lang E, et al. An evidence-based prehospital guideline for external hemorrhage control: American College of Surgeons Committee on Trauma. Prehosp Emerg Care. 2014;18: 163-73.

2. Volotovska NV, Cliff Nhokwara T, Zhulkevych IV. Changes in the glutathione systems activity of internal organs in the first hours of experimental limb ischemiareperfusion syndrome, combined with blood loss and mechanical injury. Zdobutky klinichnoi i eksperymentalnoi medytsy. 2019;1: 17-23.

3. Francischetti I, Moreno JB, Scholz M, Yoshida WB. Leukocytes and the inflammatory response in ischemiareperfusion injury. Rev Bras Cir Cardiovasc. 2010;25(4): 575-84.

4. Shatsky VV, Gudyma AA, Fedoniuk LY. [Dynamics of
9. Clasper J. C. Limb complications following prehospital tourniquet use / J. C. Clasper, K. V. Brown, P. Hill // J. R. Army Med. Corps. - 2009. - Vol. 155. - P. 200-202.

10. Morsey $\mathrm{H}$. Patients with critical ischemia of the lower limb are at risk of developing kidney dysfunction / H. Morsey, M. Aslam, N. Standfield // Am. J. Surg. - 2003. Vol. 185. - P. 360-363.

11. Concentration decrease of nitric oxide in the postischemic muscle is not only caused by the generation of O2- / F. Stoffels, F. Lohöfener, M. Beisenhirtz [et al.] // Microsurgery. - 2007. - Vol. 27, No. 6. - P. 565-568.

12. Comparison of changes in markers of muscle damage induced by eccentric exercise and ischemia/ reperfusion / Q. S. Su, J. G. Zhang, R. Dong [et al.] // Scand. J. Med. Sci. Sports. - 2010. - Vol. 20, No. 5. - P. 748-756.

13. Гудима А. А. Антиоксидантно-прооксидантний та цитокіновий баланс у пізній період комбінованої травми в експерименті / А. А. Гудима, Т. В. Кащак, К. В. Шепітько // Світ медицини та біології. - 2019. - № 1 (67). C. $42-47$.

14. Цимбалюк Г. Ю. Стан добового діурезу нирок в умовах ішемічно-реперфузійного синдрому кінцівок, травми органів черевної порожнини, ускладненої гіповолемічним шоком, та їх поєднання у ранньому періоді травматичної хвороби / Г. Ю. Цимбалюк // Здобутки клінічної та експериментальної медицини. -2018. № 3(35). - С. 163-169.

15. Tsimbalyuk G. Y. Features of transport of potassium ions in ischemia-reperfusion syndrome of lower extremities, abdominal trauma and hypovolemic shock / G. Y. Tsimbalyuk, V. O. Krylyuk // Journal of Education, Health and Sport. - 2018. - Vol. 8, No. 9. - P. 1785-1795.

16. Van de Spuy L. Complications of the arterial tourniquet / L. Van de Spuy // South Afr. J. Anaesth Analg. 2012. - Vol. 18 (1). - P. 14-18.

17. Peculiarities of impairments of absorptive-excretory and glycogen synthesis functions of the liver in the presence of acute blood loss complicated by limb ischemiareperfusion and their correction by carbacetam / I. I. Horban, A. A. Hudyma, R. V. Maksymiv, N. A. Dzhavadova // Journal of Education, Health and Sport. - 2020. - Vol. 10 (5). P. 301-314.

antioxidant-prooxidant balance of renal cortex and medulla after acute blood loss complicated by ischemia-reperfusion of the extremity, and its correction with carbacetam]. Zdobutky klinichnoi i eksperymentalnoi medytsyny. 2019;4: 144-53. Ukrainian.

5. Arutyunyan AV, Dubinina EE, Zybina NN. Methods for assessing free radical oxidation and antioxidant system of the body. Guidelines. St-Petersburg. 2000.

6. Maksymiv RV, Horban II, Strelbytska IV, Hudyma AA, Shatskyi VV, Stakhiv OV. [Prooxidant effect of arterial tourniquet and limb reperfusion]. Proceedings of the XVII Congress of the World Federation of Ukrainian Medical Societies, September 20-22. 2018. Ternopil: TSMU; 2018. Ukrainian.

7. Shatskyi VV, Hudyma AA. Significance of lipid peroxidation processes in renal excretory dysfunction in 
cases of acute blood loss complicated by limb ischemiareperfusion and its correction. Journal of Education, Health and Sport. 2019;9;11: 293-306.

8. Televiak AT. [The dynamic of indicators of lipid peroxidation and antioxidant protection in muscle tissue of the hind limbs of the rats in development of the ischemicreperfusion syndrome (experimental study)]. Zdobutky klinichnoi i eksperymentalnoi medytsyny. 2018;3(35): 1329. Ukrainian.

9. Clasper JC, Brown KV, Hill P. Limb complications following pre-hospital tourniquet use. J R Army Med. Corps. 2009;155: 200-2.

10. Morsey $\mathrm{H}$, Aslam M, Standfield N. Patients with critical ischemia of the lower limb are at risk of developing kidney dysfunction. Am. J. Surg. 2003;185: 360-3.

11. Stoffels F, Lohöfener F, Beisenhirtz M, Lisdat F, Büttemeyer $\mathrm{R}$. Concentration decrease of nitric oxide in the postischemic muscle is not only caused by the generation of O2-. Microsurgery. 2007;27;6: 565-8.

12. Su QS, Zhang JG, Dong R, Hua B, Sun J-Z. Comparison of changes in markers of muscle damage induced by eccentric exercise and ischemia/reperfusion. Scand J Med Sci Sports. 2010;20;5: 748-56.
13. Hudyma AA, Kashchak TV, Shepitko KV. [Antioxidant-prooxidant and cytokine balance in the late period of combined trauma in the experiment]. Svit medytsyny ta biolohii. 2019;1(67): 42-7. Ukrainian.

14. Tsimbalyuk GY, Krylyuk VO. Features of transport of potassium ions in ischemia-reperfusion syndrome of lower extremities, abdominal trauma and hypovolemic shock. Journal of Education, Health and Sport. 2018;8;9: 1785-95.

15. Tsymbaliuk HY. [Daily urine renal state under ischemic-reperfusion syndrome of limbs, abdominal injury with hypovolemic shock and their combination in the early period of traumatic disease]. Zdobutky klinichnoi i eksperymentalnoi medytsyny. 2018;3:(35): 163-9. Ukrainian.

16. Van de Spuy L. Complications of the arterial tourniquet. South Afr. J. Anaesth Analg. 2012;18(1): 14-8.

17. Horban II, Hudyma AA, Maksymiv RV, Dzhavadova NA. Peculiarities of impairments of absorptive-excretory and glycogen synthesis functions of the liver in the presence of acute blood loss complicated by limb ischemia-reperfusion and their correction by carbacetam. Journal of Education, Health and Sport. 2020;10(5): 301-14. 